\title{
レーザ熱処理による切りくず処理性の改善 に関する基礎的研究*
}

\author{
田中隆太郎 ${ }^{* *}$ 林 勇伝***田邊 一真 ${ }^{\dagger}$ 上田 隆司 ${ }^{* *}$ 細川 晃**
}

Fundamental Study on Improvement of Chip Controllability in Turning with Laser Heat Treatment

Ryutaro TANAKA, Yuangchuan LIN, Kazumasa TANABE, Takashi UEDA and Akira HOSOKAWA

This study deals with the trial for improvement of chip controllability in turning with selective laser heat treatment for workpiece. Selective heat treatment for carbon steel JIS S45C was carried out with Nd:YAG laser which could be transmitted through an optical fiber and shows higher absorption rate against carbon steels than $\mathrm{CO}_{2}$ laser. In turning of these selective laser heat threatened carbon steel, the chip form changed regular curl from irregular curl and chip breakability was improved compared with non-laser treated carbon steel. Surface roughness was obviously smaller comparing with non-laser treated carbon steel. Especially in the case that the depth of cut was larger, the surface roughness was smaller. As for cutting force, the principal force was slightly smaller, but the thrust force and feed force were almost the same. The cutting temperature was slightly lower. The tool wear was almost same as that in the case of non-laser treated carbon steel.

Key words: Nd:YAG Laser, heat treatment, martensite, ferrite, pearlite, carbon steel, chip control, carbide tool, surface roughness, cutting force, tool wear, cutting temperature

\section{1. 緒 論}

切削加工の高能率化をはかるために, 切削速度の高速化, さら に生産設備はライン化され昼夜を問わず自動運転されている. 連 続切削である旋削加工では, 自動運転の際, 切りくず処理性が問 題となることがある. 切りくずが被削材に絡みつき仕上げ面を擦過 することで表面品位を低下させる恐れや, 切りくずの噛みこみにより 工具の破損が引き起こされる危険性も考えられる.

工具摩耗の抑制や, 仕上げ粗さの向上, 切りくず処理性を改善 するなど目的で鋼材中に快削性添加物を含有する快削鋼として硫 黄快削鋼や鉛快削鋼, 超快削鋼など ${ }^{1)}$ 2)がある. その快削化メカニ ズムはおおよそ $\mathrm{MnS}$ による脆性付与や切削中の加工熱により被削 材中の鉛, ビスマスが溶融することによる溶融脆化や潤滑性向上で ある. しかしながら, 機械的強度や而腐食性の低下, 鉛が人体や作 業環境へ及ぼす影響, 添加物がレアメタルで高価であるなど, それ ぞれの快削鋼には問題が残る. このほかにも, 切削加工の前処理 として長手方向に浅い溝を入れる方法や放電加工機による放電痕

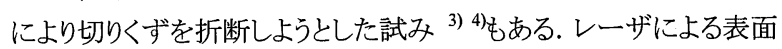
処理により切りくず改善の試みがなされたとの記述 ${ }^{3}$ があるが, 資料 としては見当たらない. また, マシニングセンタ上でのレーザを用い た機上焼入れについての報告 ${ }^{5)}$ もるが, 焼入れが切削性一及ぼ す影響について調べたものは見当たらない.

近年, レーザ発振器の小型化・高出力化に伴いその用途が拡大 し, 工作機械の複合化の傾向と相まって, 例えば, レーザ発信器を 備えたマシニングセンタとして積層光造形加工機など限られた用途 ではあるが市場で広まりつつあり, その他の切削加工機械との複合

\footnotetext{
* 原稿受付 平成 18 年 12 月 25 日

** 正 会 員 金沢大学大学院自然科学研究科 (金沢市角間町)

*** 学生会員 金沢大学大学院自然科学研究科（同上）

†金沢大学工学部（現，(株)日平トヤマ; 富山県南砺市野尻 641)
}

Table 1 Chemical compositions of work material

\begin{tabular}{|c|c|c|c|c|c|c|c|}
\hline & \multicolumn{6}{|c|}{ Chemical compositions mass $\%$} & \multirow{2}{*}{$\begin{array}{c}\text { Hardness } \\
\text { HB }\end{array}$} \\
\hline & $\mathrm{C}$ & $\mathrm{Si}$ & $\mathrm{Mn}$ & $\mathrm{P}$ & $\mathrm{S}$ & Sol.Al & \\
\hline $\mathrm{S} 45 \mathrm{C}$ & 0.44 & 0.19 & 0.74 & 0.017 & 0.018 & 0.026 & 240 \\
\hline
\end{tabular}

Table 2 Experimental conditions in laser hear treatment process

\begin{tabular}{|c|c|c|}
\hline \multicolumn{3}{|c|}{ Nd:YAG Laser (CW) } \\
\hline Wave length & $\lambda$ & $1064 \mathrm{~nm}$ \\
\hline Average pow & ver : $Q$ & $38 \sim 82 \mathrm{~W}$ \\
\hline Scan rate : & & $10 \sim 40 \mathrm{~mm} / \mathrm{s}$ \\
\hline Spot diamete & & $0.22 \mathrm{~mm}$ \\
\hline \multicolumn{3}{|c|}{ Table 3 Cutting conditions } \\
\hline Work: & & S45C (annelid) \\
\hline Tool : & & Carbide P30 (SNMN120408) \\
\hline Cutting speed : & $\mathrm{v}$ & $150 \mathrm{~m} / \mathrm{min}$ \\
\hline Depth of cut : & d & $0.1 \sim 0.5 \mathrm{~mm}$ \\
\hline Feed rate : & $\mathrm{f}$ & $0.1 \mathrm{~mm} / \mathrm{rev}$ \\
\hline Atmosphere : & & dry \\
\hline
\end{tabular}

化も期待される.

そこで本研究では, Nd:YAG レーザを用いた被削材の選択的な 改質による旋削加工時における切りくず処理性の改善を目的とし, 一般的な機械構造用炭素鋼 S45C について実験を行った. 実験で 用いた Nd:YAGレーザは $\mathrm{CO}_{2}$ レーザと比較し鋼材に照射したときの 吸収率が高く, また光ファイバで伝送が可能であり, 加工に用いる 際において柔軟な取り回しが可能であるという特徵を持つ. 実験で は, レーザ照射された被削材の断面観察とともに, 旋削加工時にお ける切りくず処理性, 仕上げ面粗さ, 切りくずの厚さ, 切削抵抗, 切 削温度および工具摩耗への影響について調査し, Nd:YAG レーザ による被削材の選択的な熱処理が切削機構へ与える影響につい 


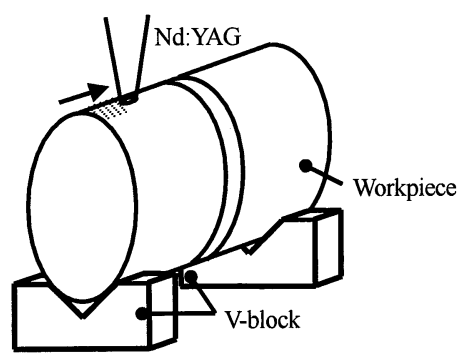

(a) Laser heat treatment

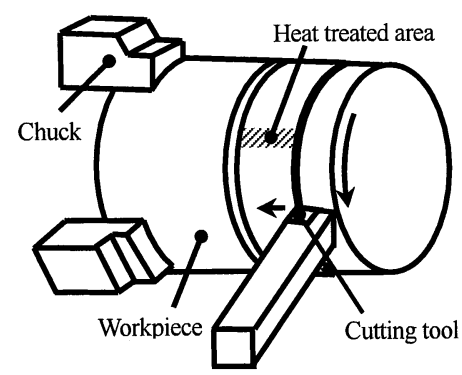

(b) Cutting test

Fig.1 Schematic illustration of experimental set up

て検討を行った.

\section{2. 実 験 方 法}

表 1 に被削材として使用した炭素鋼 S45C の化学成分および硬さ を示す. 被削材は熱間鍛造の後, $850^{\circ} \mathrm{C} て ゙ 5$ 時間保持後, 放冷で 焼きならししてある.

表 2 にレーザの照射条件を示す. Nd:YAGレーザは, 出力 38〜 $82 \mathrm{~W}$, 連続発振, スポット径 $0.22 \mathrm{~mm}$, 走査速度 $10 \sim 40 \mathrm{~mm} / \mathrm{s}$ (60-240 mm $/ \mathrm{min})$ とした. 炭素鋼の Nd:YAGレーザに対する吸収率 はおよそ $40 \%$ である ${ }^{6)}$. 吸収剂およびアシストガスは使用していな い.

被削材の断面観察用のサンプルは, レーザ照射の後, レーザの 走査方向と垂直方向に切断した. これを樹脂へ埋め込み, 研磨し た後, ナイタル溶液で腐食し, 断面の組織観察およびビッカース硬 さの分布を調べた.

切削試験は, 図 1（a)に示す長手方向にレーザを連続照射した 円筒状の被削材を, 図 1 (b)に示すように長手方向へ旋削加工する ことで行った.レーザを用いて選択的な熱処理をした被削材を, $\mathrm{CNC}$ 旋盤を用いて乾式長手旋削を行い, 切りくず処理性と工具摩 耗についてレーザ未照射の被削材と比較し評価した. 表 3 に切削 条件に示す. 切削速度は急激な工具摩耗が引き起こされることなく, 顕著な構成刃先が発生せず比較的良好な仕上げ面が得られる速 度として $150 \mathrm{~m} / \mathrm{min}$ に設定した. 切り込みを $0.1 \sim 0.5 \mathrm{~mm}$ の範囲で変 化させ, 送りは $0.1 \mathrm{~mm} / \mathrm{rev}$ の一定とした.工具は超硬合金 P30(SNMN120408)を用いた. 今回の旋削加工でチップブレーカ 一は使用していない.

工具摩耗試験の被削材として, S45C と Nd:YAG レーザを用 いて選択的な熱処理を行った $\mathrm{S} 45 \mathrm{C}$ を用いた. 切削条件は, 切 削速度 $150 \mathrm{~m} / \mathrm{min}$, 切り込み $0.4 \mathrm{~mm}$, 送り $0.1 \mathrm{~mm} / \mathrm{rev}$ とした.レ 一ザ熱処理は, 直径 $66 \mathrm{~mm}$ の円筒状の $\mathrm{S} 45 \mathrm{C}$ の長手方向にライ ン状にレーザ熱処理したものを長手方向に $120 \mathrm{~mm}$ 旋削後, 再 度同じ箇所にレーザ照射を行い直径が $58.8 \mathrm{~mm}$ となるまで切削 を続けた. 工具摩耗は工具をホルダから任意の時間毎に取り外 し, 工具顕微鏡を用いて逃げ面摩耗幅の測定を行った. また切 削終了後, 最大クレータ深さを触針粗さ計で測定した.

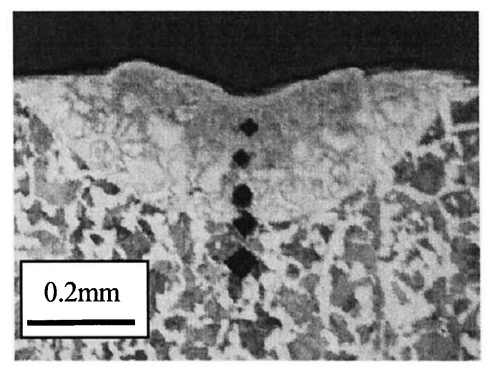

Power; $82 \mathrm{~W}$, Spot dir; $0.22 \mathrm{~mm}$, Scan rate; $10 \mathrm{~mm} / \mathrm{s}$

Fig.2 Cross section of $\mathrm{S} 45 \mathrm{C}$ after laser heat treatment with Nd:YAG Laser
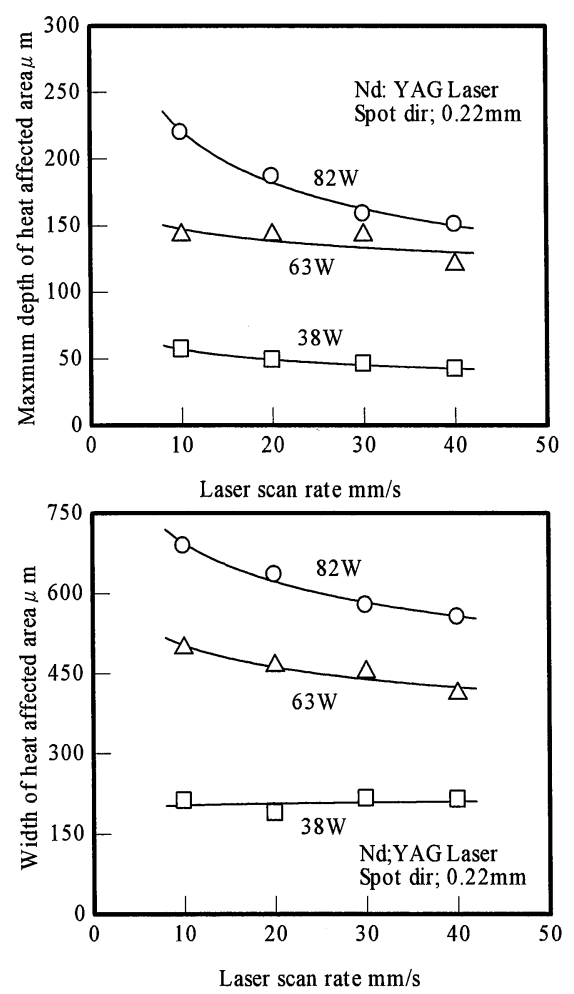

Fig.3 Influence of laser power and scan rate on the laser affected depth and width of S45C

切削抵抗の測定は, 刃物台に取り付けた ATS 式動力計を用い て計測し,アンプを介してデジタルオシロスコープで記録した. 切削抵抗は工具動力計に添付の校正曲線を用いて求めた。

切削温度の測定は, 工具-被削材熱電対法により行った. 起電 力を切削温度に校正するために校正曲線が必要となるが, 積分 球の焦点にあるクロメル-アルメル熱電対と工具または被削材 の接点をもうひとつの焦点にあるスポットヒータで加熱し, ク ロメル-アルメル熱電対に対する起電力 $\mathrm{S} 45 \mathrm{C}$ および超硬工具 P30 の熱起電力を求め, これらの差から求めた.

また, 切削後の被削材についても加工面を観察し, 触針粗さ計 を用い表面形状および粗さの測定を行った.

\section{3. 実験結果および考察}

\subsection{Ne:YAG レーザによる S45C の熱処理特性}

図 2 にレーザ照射後の $\mathrm{S} 45 \mathrm{C}$ の試料の断面についての組織写真 を示す. 試料はナイタル溶液により腐食後のものである. 写真を見 ると, フェライト-パーライト組織の母材中に半円状に組織が変化し ている部分が確認できる. 写真中のビッカース圧子による圧痕の大 きさを見ると, 明らかに母材の領域における圧痕と比べ小さくその 


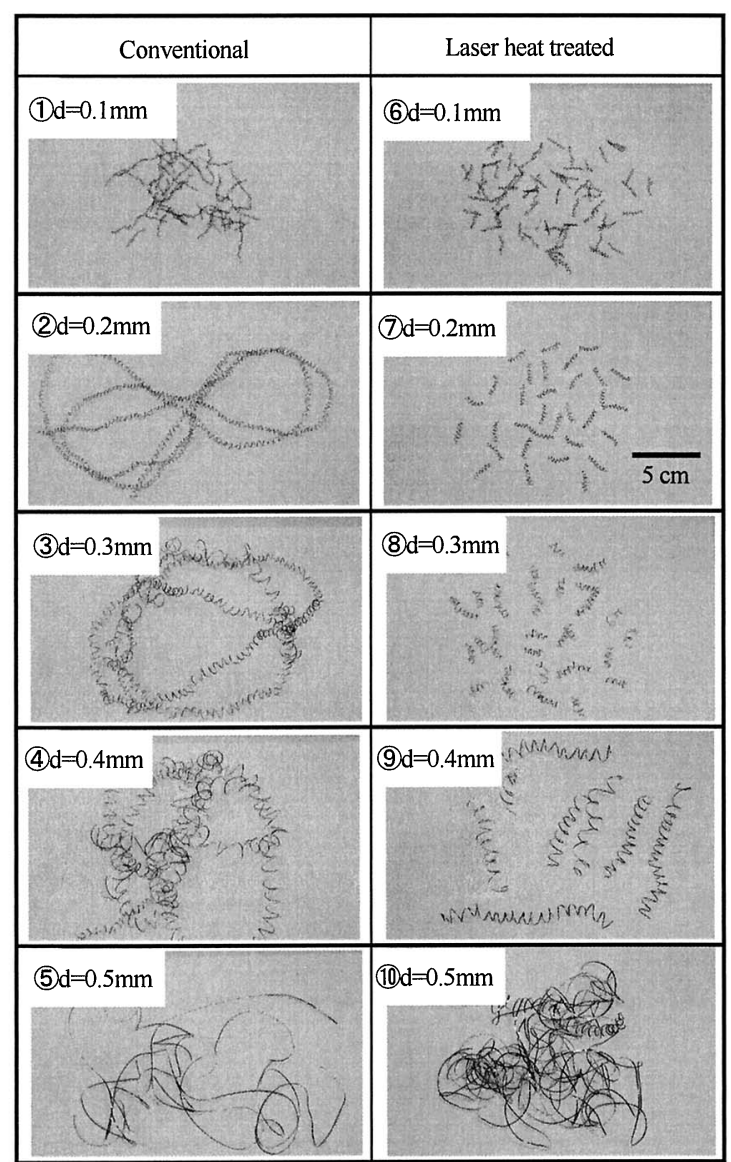

Tool: P30, v $=150 \mathrm{~m} / \mathrm{min}, \mathrm{f}=0.1 \mathrm{~mm}$, dry Laser power; $82 \mathrm{~W}$, Spot dir; $0.22 \mathrm{~mm}$, Scan rate; $10 \mathrm{~mm} / \mathrm{s}$

Fig.4 Influence of laser heat treatment for workpiece on the chip form

硬度が高いことが分かる. 組織が変化している部分にはマルテンサ イト組織が見られ，硬度も最大でHv600程度に達していた.これより レーザ照射により組織が変化したことがわかる. 図 3 にレーザ照射 によって変化を受けた組織の深さと幅を示す.レーザパワーが $63 \mathrm{~W}$ と $82 \mathrm{~W}$ の場合, レーザスポット径 $0.22 \mathrm{~mm}$ よりも, 熱影響部幅が大き い.これは被削材中の熱伝導によりレーザが直接照射されていな い部分においても温度が上昇し組織が影響を受けたと考えられる. 熱影響深さは, レーザパワーが大きく, レーザ走査速度が小さいほ どより深くまで熱影響層が得られることが分かる. また, 影響幅につ いても同様の傾向が見られた。

\section{2 切りくず折断性への影響}

図 4 に旋削加工時に生成された切りくず形態を示す. 被削材の 一方は, レーザパワー $82 \mathrm{~W}$, 送り $10 \mathrm{~mm} / \mathrm{s}$ で熱処理を行っている. 図 2 および図 3 に示すようにこの条件でレーザ熱処理を行うと熱影 響部は幅 $1 \mathrm{~mm}$, 深さ $0.3 \mathrm{~mm}$ である. 切りくずの厚さは送りの約 2 倍 であることから, 被削材が 1 回転する間に生成される切りくずは全周

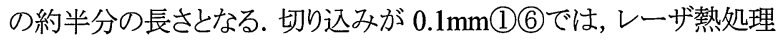
後の有無にかかわらず切りくずが適度な長さで折断されている.レ 一ザ熱処理なしと比ベレーザ熱処理後の場合の切りくずの長さが 短い.レーザ熱処理後では, 被削材が 1 回転する間に生成される 切りくず長さ(約 $9 \mathrm{~cm}$ )より明らかに短い切りくずも見受けられ，切り 込みに対する送りの比が大きいために折断した場合とレーザによる 損傷部で折断した場合が混在していると考えられる. 切り込みが $0.2 \mathrm{~mm}$ でレーザ熱処理なし(2)では切りくずは折断されることなく連
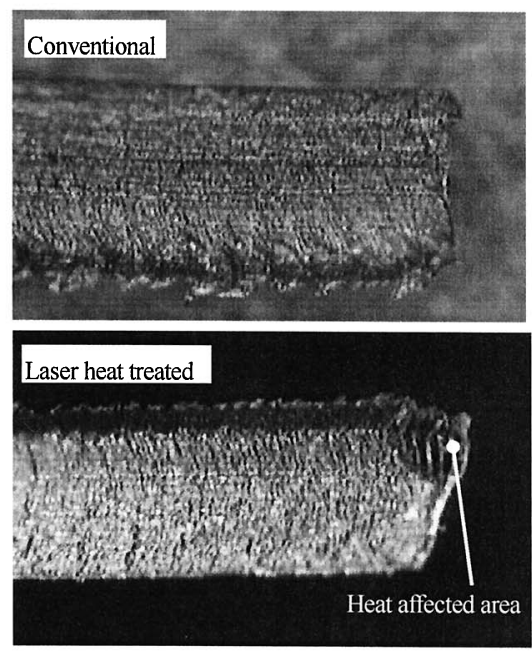

Tool: $\mathrm{P} 30, \mathrm{v}=150 \mathrm{~m} / \mathrm{min}, \mathrm{d}=0.4 \mathrm{~mm}, \mathrm{f}=0.1 \mathrm{~mm}$, dry Laser power; $82 \mathrm{~W}$, Spot dir; $0.22 \mathrm{~mm}$, Scan rate; $10 \mathrm{~mm} / \mathrm{s}$ Fig.5 Microphotograph of the ends of chip in turning S45C
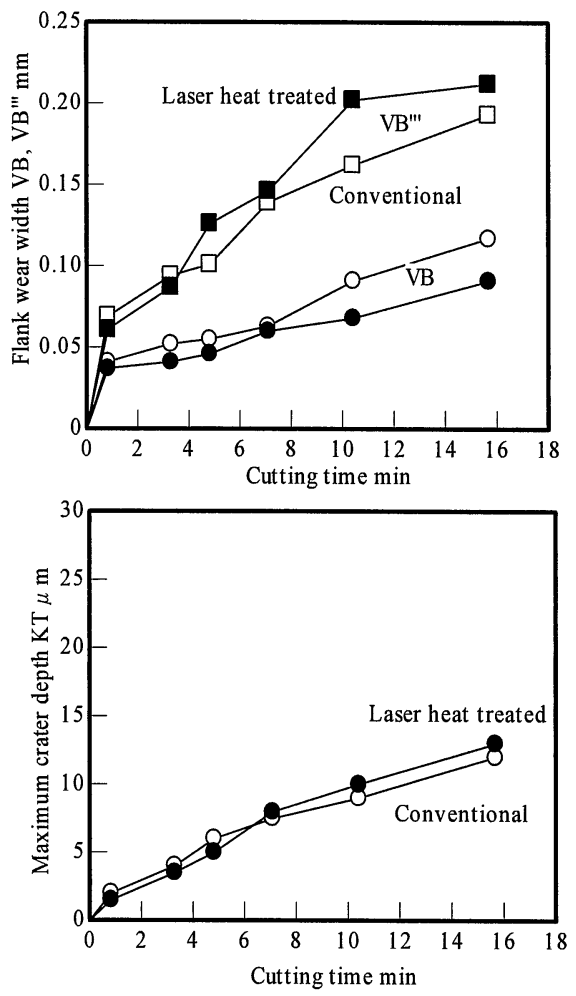

Tool: $\mathrm{P} 30, \mathrm{v}=150 \mathrm{~m} / \mathrm{min}, \mathrm{d}=0.4 \mathrm{~mm}, \mathrm{f}=0.1 \mathrm{~mm}$, dry Laser power; $82 \mathrm{~W}$, Spot dir; $0.22 \mathrm{~mm}$, Scan rate; $10 \mathrm{~mm} / \mathrm{s}$

Fig.6 Wear progress cruces of carbide tool P30 in turning S45C and selective laser heat treated carbon steel

続であるが, レーザ熱処理後(7)では切りくずがほぼ同じ長さで分断 されている. 切り込みが $0.3 \mathrm{~mm}$ においてもレーザ熱処理なし(3)はら せん状の一部不規則な連続した切りくずが生成されているが, レー ザ熱処理あり8では, 切りくずは 6,7 巻き程度で折断されており, その長さはほぼ半周分に近く, 折断された切りくずの両端において レーザ熱処理による熱的な損傷が確認できる.このことからレーザ 熱処理部において, かなり高い確率で切りくずが折断されていると 考えられる. 切り込みが $\mathrm{d}=0.4 \mathrm{~mm}$ ではレーザ熱処理なし(4)は不規 則ならせん状切りくずであるが, レーザ熱処理あり(9)では, 切りくず 


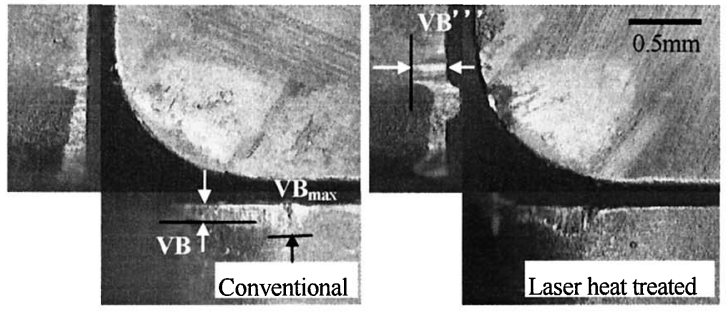

Tool: $\mathrm{P} 30, \mathrm{v}=150 \mathrm{~m} / \mathrm{min}, \mathrm{d}=0.4 \mathrm{~mm}, \mathrm{f}=0.1 \mathrm{~mm}$, dry Laser power; $82 \mathrm{~W}$, Spot dir; $0.22 \mathrm{~mm}$, Scan rate; $10 \mathrm{~mm} / \mathrm{s}$

Fig.7 Wear patterns of carbide tool P30 after turning S45C and selective laser heat treated carbon steel

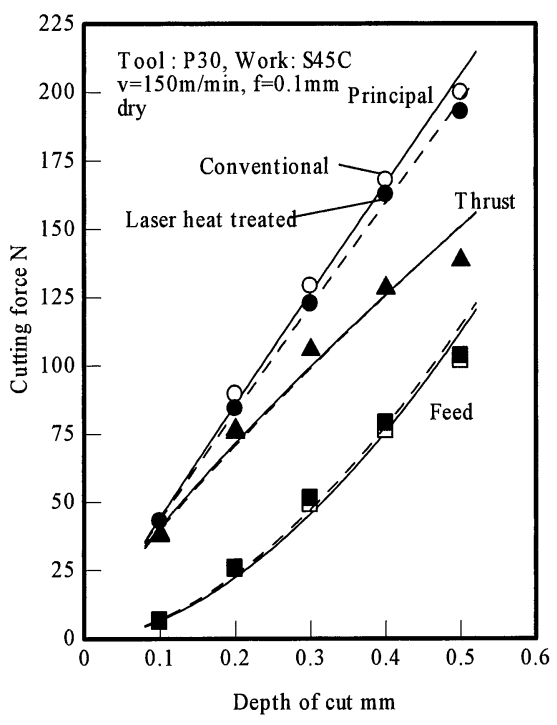

Laser power; $82 \mathrm{~W}$, Spot dir; $0.22 \mathrm{~mm}$, Scan rate; $10 \mathrm{~mm} / \mathrm{s}$ Fig.8 Influence of laser heat treatment for workpiece on the cutting force

が 10 巻き程度で定期的な長さで折断されているが 1 周分に相当す る切りくず長さより長い. したがって, 切りくずがすべてのレーザ照 射痕において折断されているのではなく, 切りくずがある程度の長 さまで生成し, その後, 切りくずの自重や遠心力により折断に至っ たと思われる.このときの折断部においてレーザ照射痕が確認でき た. 切り込みが $\mathrm{d}=0.5 \mathrm{~mm}$ では, どちらの場合も連続した切りくずが 観察されたが,レーザ熱処理なし(5)がリボン状であるのに対し、レ 一ザ熱処理あり110では, リボン状の中に一部らせん状の部分も見ら れる. そして所々にレーザ照射による照射痕が周期的に観察できる. ほとんどの場合, その照射痕において切りくずが折断することはな かったが, 所々折れかかり鈍角に曲がっている部分が観察できる. また, レーザ熱処理なしの場合の切りくずと比較すると, 切りくずの カール半径が小さくなっていることが分かる.

前処理により被削材表面に溝を入れ切りくずを折断しようとする 場合, 切り込みのおよそ 5 割以上の溝深さが必要であり, 8 割を超 えると仕上げ面に影響を及ぼすとされている. 今回の実験において $\mathrm{d}=0.4 \mathrm{~mm}$ では熱影響深さが切り込みの 6 割であるが, 切りくずの形 状に変化が見られたが折断に至ることはなく, $\mathrm{d}=0.3 \mathrm{~mm}$ 以下の場 合, 熱影響深さが切り込みの 8 割以上となり折断性の向上が認めら れた. レーザ熱処理により被削材の部分改質により切りくずを折断 させる方法は, 溝入れのように完全に被削材の一部を除去する場 合の除去深さより梁い熱処理深さが必要であることが分かる.

図 5 に折断後の切りくず端部の拡大写真を示す. 慣用時は切削 点近傍で切りくずが折断されなかったので切りくずが生成後被削材

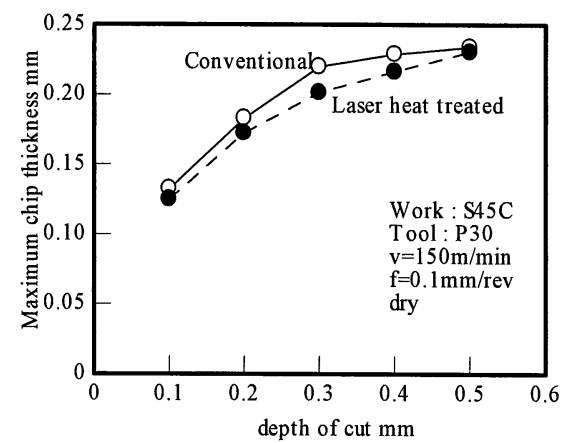

Laser power; $82 \mathrm{~W}$, Spot dir; $0.22 \mathrm{~mm}$, Scan rate; $10 \mathrm{~mm} / \mathrm{s}$

Fig.9 Influence of laser heat treatment for workpiece on the chip thickness

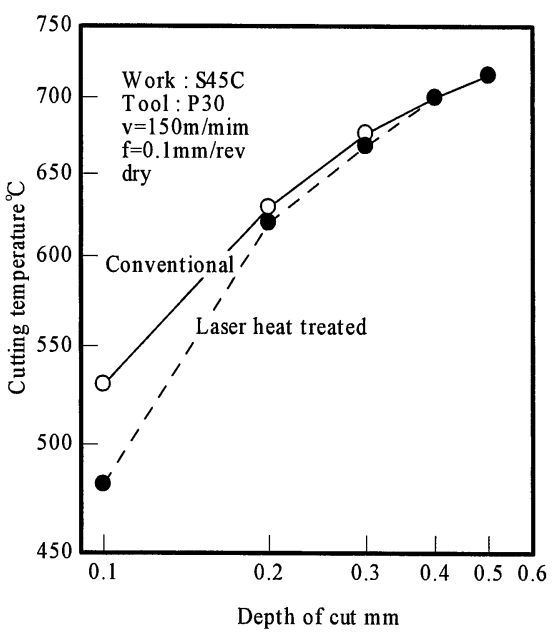

Laser power; $82 \mathrm{~W}$, Spot dir; $0.22 \mathrm{~mm}$, Scan rate; $10 \mathrm{~mm} / \mathrm{s}$

Fig.10 Cutting temperature in turning $\mathrm{S} 45 \mathrm{C}$ and selective laser heat treated carbon steel

やチャックに絡みつき強制的に折断された場合のサンプルである. レーザにより選択的な熱処理を行った被削材を旋削したときに生成 される切りくずの端部は, 明らかに未処理の場合と異なり, レーザに よる照射跡が確認できることから,レーザ熱処理により脆性が高い マルテンサイト組織に変化し, この部分において切りくずが折断さ れ, 結果として切りくずの折断性が向上したと考えられる. マルテン サイト相を適度に含む炭素鋼の切りくず処理性が優れていることが 知られているが 7), レーザによる被削材の部分的なマルテンサイト 化でも折断性向上に効果があることが分かった.

\section{3 切削特性へ及ぼす影響}

レーザ照射による被削材の部分熱処理が切削特性へ及ぼす影 響として, 工具摩耗, 切削抵抗, 切削温度, および仕上げ面粗さに ついて調べた.

図 6 に S45C 切削時の工具摩耗進行線図を示す. 横逃げ面平行 部摩耗幅 VB は, 切り込みの 1/2 の位置における值である. 前逃げ 面境界部摩耗幅 VB" ”およびクレータ深さ切削終了後における摩 耗幅の大きさはレーザ熱処理を行った場合の方が若干小さいが, 初期摩耗およびその後の摩耗進行速度に大きな違いは認められな い. また, 逃げ面最大摩耗幅 VBmax もレーザ熱処理のほうがやや 大きいが有意な差とはいえない。

図 7 に切削後の工具摩耗形態を示す.レーザ照射した場合, 周 期的に母材より硬度が高い部分に接するが, 異常な摩耗は認めら れず,レーザ熱処理なしと比較しても違いは認められない。

図 8 に切削抵抗を示す. 切削抵抗は,レーザ熱処理後の場合, 


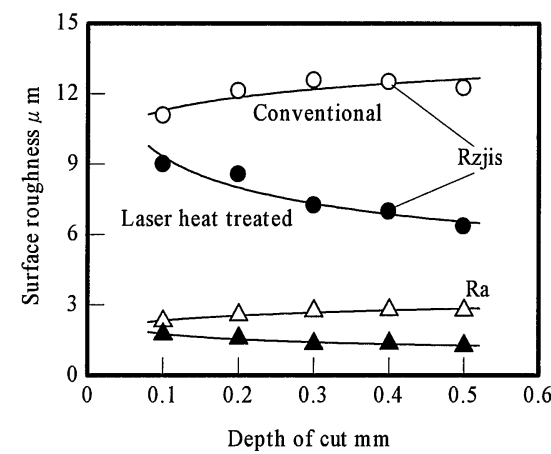

Tool: $P 30, v=150 \mathrm{~m} / \mathrm{min}, \mathrm{f}=0.1 \mathrm{~mm}$, dry Laser power; $82 \mathrm{~W}$, Spot dir; $0.22 \mathrm{~mm}$, Scan rate; $10 \mathrm{~mm} / \mathrm{s}$

Fig.11 Influence of laser heat treatment for workpiece on the surface roughness

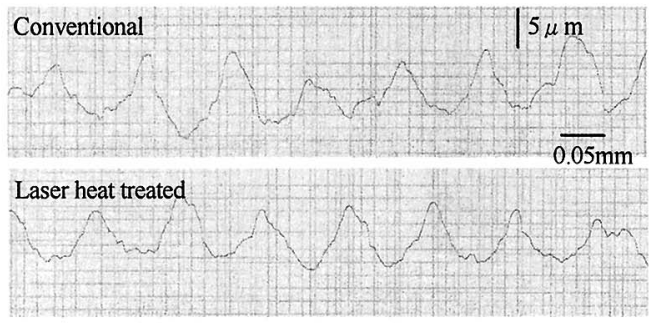

Tool: P30, $\mathrm{d}=0.4 \mathrm{~mm}, \mathrm{v}=150 \mathrm{~m} / \mathrm{min}, \mathrm{f}=0.1 \mathrm{~mm}$, dry

Laser power; $82 \mathrm{~W}$, Spot dir; $0.22 \mathrm{~mm}$, Scan rate; $10 \mathrm{~mm} / \mathrm{s}$

Fig.12 Profile curve of work materials after turning with carbide tool P30

レーザ熱処理なしと比べ背分力, および送り分力はほぼ同じ值を 示し, 主分力については若干の減少が見られた。

図 9 に切りくずの平均厚さを示す. 3 次元切削においての切りくず の厚さは一定でなく, 切り込み方向で変化するが, 今回の実験では 切りくずのほぼ中央部をマイクロメータで測定し, 10 回の測定值の 平均值を切りくず厚さとした. いずれの被削材切削時も, 切り込み の増加に伴い最大切りくず厚さが増加している.レーザ熱処理後の 被削材の場合, レーザ熱処理なしの被削材と比べ切りくず厚さが小 さいことが分かる。

図 10 に切削温度を示す.レーザ熱処理の有無の関わらず, 切り 込みが増加するにしたがって切削温度が上昇する傾向が見られる. 切り込みが小さいほど, レーザ熱処理なしと比ベレーザ熱処理後の 被削材を切削した時の温度がわずかではあるが低くなっている. ま た, 切り込みが $0.4 \mathrm{~mm}$ と $0.5 \mathrm{~mm}$ ではほぼ同じ温度を示している.

図 11 に旋削加工後の仕上げ面粗さとして算術平均粗さと十点平 均粗さRzjis を示す.いずれも 10 回測定を行った平均值である. Ra, Rzjis ともにレーザ熱処理なしと比べ明らかに小さい粗さを示す.レ 一ザ熱処理なしの場合, 切り込みが変化してもほぼ一定の粗さを示 すが,レーザ熱処理後では切り込みが大きいほど小さな粗さを示す.
図 12 に旋削加工後の仕上げ面の送り方向における断面プロファイ ルを示す.レーザ熱処理なしは, ピーク部, 谷部ともに高さが一定 でない.レーザ熱処理後では, 工具の形状が規則的に転写されて いることが分かる。

\section{4. 結 論}

炭素鋼 S45C について, Nd:YAGレーザ照射後の断面組織観察 および硬さ測定した. また円筒表面の長手方向へレーザ照射した 被削材について旋削加工を行い，被削材の選択的な熱処理が切 削特性へ及ぼす影響について調査し，レーザ熱処理なしの被削材 切削時と比較し検討を行った結果, 以下の結論が得られた。

1) Nd:YAGレーザを用いた炭素鋼 S45C の選択的な熱処理によ り，切りくず処理性の改善が可能である. 切りくずの形態が不 規則ならせん形状から規則的ならせん形状に変化し，切りくず の厚さが薄くなった.

2) 背分力, および送り分力はほぼ同じ值を示し, 主分力につ いて最大で約 5\%の減少が認められた。

3）算術平均粗さ Ra，十点平均粗さ Rzjis ともにレーザ未照射と 比べ明らかに小さい值を示し，切り込みが大きいほどその 傾向が顕著である。

4) 工具摩耗は，レーザ熱処理した被削材の方が逃げ面平行部 摩耗幅ではわずかに小さい值を示し, 境界部付近ではやや大 きな摩耗を示したが, 欠損など突発的な損傷は認められず, 両者に大きな違いは認められなかった。

本手法は, 切削条件に応じてレーザ熱処理深さをコントロールす ることが可能であり, 切りくず折断性だけでなく, 更なる検討が必要 であるが被削材が小径で切削速度が高く出来ないような場合にお いて仕上げ面粗さを向上できる可能性があると言える.

\section{謝 辞}

本研究を遂行するにあたり多大なご支援いただきました JFE 条鋼に記して感謝の意を表します。

\section{参 考 文 献}

1) 奥島啓弐, 岩田一明:金属材料の被削性に関する研究(鉛快削鋼の切り くず生成),日本機械学会論文集(第 3 部), 28, 187 (1962) 404

2) 例えば, 中島利勝, 鳴瀧則彦:機械加工学, コロナ社 (1983) 106.

3) 新井 実:切りくず処理の基礎と応用, 日刊工業新聞社 (1990) 109.

4) 中山一雄, 上原邦夫:新版機械加工, 朝倉書店 (1997) 89 .

5) 廣垣俊樹, 中川平三郎, 速水雅人, 喜田義宏, 垣野義昭, 山路伊和夫: YAG レーザを用いた機上焼入れに関する研究-各種合金鋼の焼入れ特 性-精密工学会誌, 66,5(2000)704.

6) 新井武二, はじめてのレーザプロセス初版, 工業調查会, (2004) 93

7）山本重男, 荒木透, 中島宏興:マルテンサイト相を混在させた鋼の切削 挙動, 鉄と鋼, 71, 16 (1985) 107.

8) 新井 実: 切りくず処理の基礎と応用, 日刊工業新聞社 (1990) 27 .

9) 山内雅子, 堀内 宰, 村上良彦, 菅野浩人, 潞谷秀雄: タップ立て用切り くず分断工具の開発(第 1 報) - 工具の試作と有効性一, 精密工学会誌, 70, 12 (2000) 1565 